\title{
FATLIQUORING POTENTIALS OF SULPHONATED Hura crepitans L. SEED OIL
}

\author{
Adachukwu NKWOR ${ }^{* 1}$, Pius UKOHA ${ }^{2}$, Will WISE ${ }^{3}$, Karl FLOWERS ${ }^{3}$ \\ ${ }^{1}$ Department of Chemistry/Biochemistry/Molecular Biology, Alex Ekwueme Federal University Ndufu-Alike Ikwo, P.M.B 1010, \\ Abakaliki, Ebonyi State, Nigeria, adachukwu.nkwor@funai.edu.ng; adannkwor@yahoo.com \\ 2Department of Pure and Industrial Chemistry, University of Nigeria, Nsukka, Enugu State, Nigeria, pius.ukoha@unn.edu.ng \\ ${ }^{3}$ Institute for Creative Leather Technologies, The University of Northampton, Park Campus, \\ Boughton Green Road, NN2 7AL, Northampton, United Kingdom, will.wise@northampton.ac.uk, karl@authenticae.co.uk
}

Received: 07.02.2019

Accepted: 16.05 .2019

https://doi.org/10.24264/Ifj.19.2.2

FATLIQUORING POTENTIALS OF SULPHONATED Hura crepitans L. SEED OIL

ABSTRACT. Fatliquors are oil-in-water emulsions required in leather processing for the purpose of leather lubrication. They ensure that the collagenic fibres do not stick together on drying and as a consequence make the leather flexible. In this work sulphonated oil with negligible inorganic salt content has been synthesised from Hura crepitans L. seed oil. Both the unsulphonated and sulphonated oils were characterized by DSC, FT-IR, ${ }^{1} \mathrm{H}$ NMR, ${ }^{13} \mathrm{C}$ NMR, and ${ }^{13} \mathrm{C}$ NMR DEPT. The sulphonated oil and its blend with $7.5 \%$ raw castor oil were applied onto light leather and compared with commercial fatliquor in the processing of shoe upper leather. The characteristics of the processed trial leathers were comparable with similar leathers made with commercially available fatliquors. This work raises the possibility of increasing the range of commercially viable, sustainable fatliquors in the leather industry.

KEY WORDS: Hura crepitans L., fatliquor, leather, lubrication, sulphonated

POTENTIALUL DE UNGERE AL ULEIULUI SULFONAT DIN SEMINTE DE Hura crepitans L.

REZUMAT. Agenţii de ungere sunt emulsii de tip ulei-în-apă necesare la prelucrarea pieilor pentru ungerea acestora. Aceştia împiedică lipirea fibrelor colagenice la uscare şi, prin urmare, fac pielea flexibilă. În această lucrare s-au sintetizat uleiuri sulfonate cu conţinut neglijabil de săruri anorganice din uleiul de seminţe de Hura crepitans L. Atât uleiurile nesulfonate cât şi cele sulfonate au fost caracterizate prin DSC, FT-IR, RMN ${ }^{1} \mathrm{H}, \mathrm{RMN}{ }^{13} \mathrm{C}$ şi RMN DEPT ${ }^{13} \mathrm{C}$. Uleiul sulfonat şi amestecul său cu 7,5\% ulei de ricin brut au fost aplicate pe piele uşoară şi au fost comparate cu grăsimile comerciale utilizate la prelucrarea pielii pentru feţe de încălţăminte. Caracteristicile probelor de piele prelucrate au fost comparabile cu cele ale pieilor similare fabricate utilizând agenţi de ungere disponibili în comerţ. Această lucrare prezintă posibilitatea lărgirii gamei de agenţi de ungere sustenabili şi viabili din punct de vedere comercial pentru industria de pielărie.

CUVINTE CHEIE: Hura crepitans L., ungere, piele, lubrifiere, sulfonat

LE POTENTIEL DE L'HUILE SULFONÉE DE GRAINES DE Hura crepitans L. COMME LIQUEUR GRASSE

RÉSUMÉ. Les liqueurs grasses sont des émulsions huile dans eau nécessaires pour la nourriture du cuir. Elles empêchent les fibres de collagène de coller pendant le séchage et rendent donc le cuir souple. Dans cet article, des huiles sulfonées avec une teneur négligeable en sels inorganiques de l'huile de graines de Hura crepitans L. ont été synthétisées. Les huiles non sulfonées et sulfonées ont été caractérisées par DSC, FT-IR, RMN ${ }^{1} \mathrm{H}, \mathrm{RMN}{ }^{13} \mathrm{C}$ et RMN DEPT ${ }^{13} \mathrm{C}$. L'huile sulfoné et son mélange avec $7,5 \%$ d'huile de ricin brute ont été appliquées sur un cuir léger et ont été comparées aux liqueurs grasses commerciales utilisées dans le traitement du cuir pour les chaussures. Les caractéristiques des échantillons de cuir traités étaient comparables à celles de peaux similaires fabriquées avec des liqueurs grasses disponibles dans le commerce. Cet article présente la possibilité d'élargir la gamme de liqueurs grasses durables et commercialement viables pour l'industrie du cuir.

MOTS CLÉS : Hura crepitans L., liqueur grasse, cuir, lubrification, sulfoné

\footnotetext{
"Correspondence to: Adachukwu NKWOR, Department of Chemistry/Biochemistry/Molecular Biology, Alex Ekwueme Federal University Ndufu-Alike, P.M.B 1010, Abakaliki,Ebonyi State, Nigeria; email: adachukwu.nkwor@funai.edu.ng; adannkwor@yahoo.com
} 


\section{INTRODUCTION}

Hura crepitans L., also known as the sandbox tree, possumwood, or jabillo, is an evergreen perennial tropical plant belonging to the family Euphorbiaceae [1]. In Africa, these trees are usually planted as shade trees for roadsides and are also widely used to provide shade in front of residential, public buildings and parks. The trees are about 9 metres tall on the average. The bark is covered with lots of short spines; the woody fruits bear a resemblance to small pumpkin pods in which the seeds are housed with about 10-13 seeds in a pod. The seeds of these trees, when mature and dried, usually explode mechanically, littering the environment - thereby constituting a waste. These brown seeds have average diameters of about 1-5 cm [2].

These seed kernels contain a very high percentage of non-edible, golden yellow coloured oil [3]. Although several attempts have been made by researchers to proffer uses of this oil, such as metal soap production [4], biodiesel [5], it presently has no known commercial use. Other means of turning these oils into wealth are being researched; this work on sulphonation and subsequent use as a fatliquor in the leather industry is one example.

The leather industry makes use of a process that converts animal hide (or skin) into a non-putrescible substrate. During this process natural fat from the animal hide is removed to aid penetration of water born chemicals. When tanned leather without fatliquor is dried it produces a hard, intractable material which is difficult to work with; this is due to the collagen fibres sticking together. The inclusion of fatliquor (oil-in-water emulsion) into leather is often the last of the wet processing stages of leather manufacture and lubricates the leather fibres preventing this sticking and producing softer leather. It also reduces the frictional forces between the leather fibres thereby making them slide over one another easily, improving the flexibility, tensile strength and other mechanical /physical properties of leather [6].

Most natural oils (from animal and plant sources) used in fatliquor production have major food uses and this unhealthy competition affects a nation's total available reserve [7-9].

This paper describes the use of $H$. crepitans seed oil for the preparation of a sulphonated leather fatliquor and its consequent use in the processing of a leather shoe upper. This research gives a possible commercial application for this abundant, underutilized, non-edible oil.

\section{EXPERIMENTAL}

\section{Materials and Methods}

Mature and dried $H$. crepitans pods were collected from Fatilami Park in Abakaliki, Ebonyi State, Nigeria. Wet blue goat skins were obtained from the tannery at the Institute for Creative Leather Technologies (ICLT), The University of Northampton (UoN), Northampton, United Kingdom. Reagents used in the laboratory for synthesis and analysis were of analytical grade while those used for leather processing were of commercial/industrial grade. The samples of pods, seeds and leaves were identified in the Biology unit of the department of Biology/ Microbiology and Biotechnology of the Alex Ekwueme Federal University Ndufu-Alike, Ebonyi State, Nigeria and voucher samples kept. The pods were cut open and the seeds removed. The seeds were manually decorticated and the endocarp gently removed to get the creamy white cotyledons. These creamy white cotyledons were sun dried for five days and the cotyledons were coarsely ground (approximately $2 \mathrm{~mm}$ ) using the kitchen hand grinder before extraction [3]. The extraction of the oil from the seeds was carried out in a soxhlet apparatus using $\mathrm{n}$-hexane as a solvent.

\section{Characterisation of H. crepitans Oil}

Physicochemical properties of $H$. crepitans oil ( $\mathrm{HCO}$ ) were determined according to the methods recommended by the Society of Leather Chemists and Technologists (SLTC, 1996). Fatty-acid composition of HCO was determined using its methyl ester prepared with the method described by Adewuyi et al. [5] on an Agilent 19091S-433HP-5MS gas chromatograph attached to a mass spectrometer. The injection and detection temperatures were 280 and $300^{\circ} \mathrm{C}$ respectively. Helium was used as the carrier gas at a flow rate of $20 \mathrm{ml} / \mathrm{min}$. The area percentages were recorded with a standard Chemstation Data system. For the mass spectrometry, an ACQ 
mode scanner (with scan range of 15-500 atomic mass unit and voltage of 2094) was used and the mass spectra were compared with the NIST11 mass spectral library.

Differential scanning calorimetry (DSC) of the oil was performed using a DSC 2 Star System (Mettler Toledo). The purge gas (nitrogen) had a flow rate $\sim 60 \mathrm{ml} / \mathrm{min}$. Samples of oil, of between 5-7 mg, were weighed into low pressure aluminium crucibles, and sealed hermetically. The sealed crucibles were pierced prior to analysis [10]. An empty, hermetically sealed aluminium crucible with a pinhole was used as a reference. A temperature profile of -80 to $180^{\circ} \mathrm{C}$ was run using the following temperature program: $-80^{\circ} \mathrm{C}$ isotherm for $3 \mathrm{~min}$; dynamic ramp at $-80^{\circ} \mathrm{C}$ to $180^{\circ} \mathrm{C}$ (at $10^{\circ} \mathrm{C} \mathrm{min}{ }^{-1}$ ), isotherm at $180^{\circ} \mathrm{C}$ for 3 min; isotherm at $30^{\circ} \mathrm{C}$ for $2 \mathrm{~min}$. The resulting DSC data was analysed for peak temperature, onset temperature and melting temperature for comparison. All DSC experiments were carried out in triplicate and average values are reported. Melting temperature was considered to be the temperature at the end of the melting transition [11].

\section{Sulphonation Process}

Concentrated sulphuric acid $(45 \mathrm{ml})$ was added dropwise into $150 \mathrm{~g}$ of $\mathrm{H}$. crepitans seed oil (with constant stirring at $20^{\circ} \mathrm{C}$ for 2 h). The crude mass was dissolved in $450 \mathrm{ml}$ of ethanol, and neutralised using $15 \% \mathrm{NaOH}$ (solubilised in methanol). The salts were filtered off under vacuum. The solvent was removed and recovered using a rotary evaporator. The resulting sulphonated oil was ready for use.

\section{Characterisation of the Sulphonated Oil}

To investigate the presence of $\mathrm{H}-\mathrm{C}-\mathrm{S}$ and $\mathrm{H}-\mathrm{C}-\mathrm{O}-\mathrm{S}$ group in the sulphonated fatliquor, the oils were characterised by FT-IR measurement $\left(600-4000 \mathrm{~cm}^{-1}\right)$, normal resolution of $4 \mathrm{~cm}^{-1} \mathrm{using}$ a Shimadzu $8400 S$ FT-IR instrument (Shimadzu, Milton Keynes, UK). ${ }^{1} \mathrm{H}$ nuclear magnetic resonance (NMR), ${ }^{13} \mathrm{C}$ NMR and distortionless enhancement by polarization transfer (DEPT) ${ }^{13} \mathrm{C}$ NMR, spectra of both the unsulphonated and sulphonated oils were acquired on a Bruker Biospin ${ }^{\circledR}$ AV500 - $5 \mathrm{~mm}$ BBO probe with $\mathrm{Z}$ axis gradient, TOPSPIN $\vee 2.1,{ }^{1} \mathrm{H}=500.13 \mathrm{MHz}$, ${ }^{13} \mathrm{C}=125.76 \mathrm{MHz}$ (Brucker, Coventry, UK). The thermal behaviour of the unsulphonated and sulphonated oils was determined using the Mettler DSC 2 Star System in temperature range of -80 to $180^{\circ} \mathrm{C}$.

\section{Physicochemical Tests on the Sulphonated Oil}

The specific gravity, $\mathrm{pH}$, stability of the emulsion, total organic $\mathrm{SO}_{3}$ and percentage ash were determined according to the standard methods recommended by the Society of Leather Chemists and Technologists [12].

\section{Fatliquoring Process}

Wet blue goat skin, shaved at 1.2-1.3 $\mathrm{mm}$ was divided into four quarters such that the sampling positions (BS EN ISO 2418:2002) [13] were uniformly represented in all the four quarters. Further treatments on each of the four quarters of the wet blue goat skins labelled NC, $\mathrm{PC}, \mathrm{A} 1$ and $\mathrm{A} 2$ respectively were simultaneously carried out (with the aid of four separate tanning drums/ baths) using a conventional shoe upper manufacturing process (fatliquoring process) (ICLT SR 15/31) [14].

A negative control (designated NC) was processed without any fatliquor; a positive control (designated PC) was processed using a commercial fatliquor, Trupon DXV (Trumpler Gmbh, Worms, Germany, an imported fatliquor commonly used in the Nigerian leather industry). Sample A1 was processed using pure sulphonated $H$. crepitans oil; Sample A2 was processed using a blend of pure sulphonated H. crepitans oil and $7.5 \%$ raw castor oil. Leather dyeing was omitted to enable the Sudan IV staining (for fatty substances) to be carried out effectively after the leather manufacture.

The chrome tanned leather was wet back by the addition of water (300\%) and wetting agent-Bermanol WAU $(0.2 \%)$ in the drums at a temperature of $30^{\circ} \mathrm{C}$. After 20 minutes run, the water was drained. It was then neutralised by addition of water $(100 \%)$, sodium formate $(1 \%)$ for 5 minutes and sodium bicarbonate $(0.25 \%)$ for 30 minutes at $35^{\circ} \mathrm{C}$, drained, washed with water $(200 \%)$ and drained. On addition of water (100\%) and replacement syntan (Trupotan GDL) $(6 \%)$ in the drum, it was run for 15 minutes and vegetable tannin added at $30^{\circ} \mathrm{C}$ and allowed to run for 30 minutes. Water $(200 \%)$ and Acrylic resin (3\%) were added and allowed to run for 
another 30 minutes at $35^{\circ} \mathrm{C}$ before drainage. It was further washed with water (200\%) for 5 minutes at $50^{\circ} \mathrm{C}$ and drained. Sulphonated Hura crepitans oil, labelled A2 mixed with water (1:3) $(8 \%)$ was added and allowed to run for 50 minutes at $50^{\circ} \mathrm{C}$. Formic acid $(1 \%)$ was added and allowed to run for 20 minutes, washed for 10 minutes twice and horse dried.

\section{Mechanical / Physical Properties of Leather}

All leather samples: NC, PC, A1 and A2 were conditioned according to BS EN ISO 2419:2002 [15] prior to staking twice using a Cartigliano PAL 160 leather staking machine (Cartigliano) and subsequent mechanical testing.

The mechanical properties of leather samples were all determined using standards; softness (BS EN ISO 17235:2015) [16], tensile strength (BS EN ISO 3376:2011) [17], elongation at break and tear strength of leather (BS EN ISO 3377-2:2011) [18] and grain strength (BS EN ISO 3379:2015) [19]. Thin cross sections $(50 \mu \mathrm{m})$ of the leather samples were cut with a Leica 1850 cryostat microtome (Leica, Wetzler, Germany) (set at $-20^{\circ} \mathrm{C}$ ) and used in the Sudan (IV) stain test for the determination of extent of penetration of the fatliquors between the leather fibrils.

\section{RESULTS AND DISCUSSIONS}

\section{Characterisations}

\section{Fatty Acid Composition}

The fatty acid composition of unsulphonated $H$. crepitans oil ( $\mathrm{HCO})$ is shown in Table 1.

Table 1: Fatty acid profile of the extracted oil

\begin{tabular}{cc}
\hline Fatty acid & $\begin{array}{c}\text { Percentage } \\
\text { composition }\end{array}$ \\
\hline Palmitic acid & 27.54 \\
Oleic acid & 27.24 \\
Linoleic & 33.06 \\
Linolenic & 7.45 \\
$\sum$ Saturated fatty acids & 27.54 \\
$\Sigma$ Unsaturated fatty acids & 67.75 \\
Others & 4.71 \\
\hline
\end{tabular}

It was observed that linoleic acid (33.06\%) which is an unsaturated fatty acid is the main fatty acid present in $\mathrm{H}$. crepitans oil. Other major fatty acids present are oleic acid (27.24\%) and palmitic acid (27.54\%). The iodine value of the unsulphonated oil (Table 2) is consistent with the total unsaturated fatty acids (67.75\%). The double bonds present in the unsaturated fatty acid were targets in the sulphonation process.

\section{Physico-chemical Properties}

The physico-chemical properties of unsulphonated $\mathrm{H}$. crepitans oil ( $\mathrm{HCO}$ ) and sulphonated $H$. crepitans oil (SHCO) are shown in Table 2. A high percentage of oil clearly indicates that $H$. crepitans seed contains a sufficiently large quantity of oil which can be chemically modified for the synthesis of fatliquor via sulphonation. The oil yield value of $52.76 \%$ is in close agreement with what is obtained for the seed (53.61\%) as reported by Okolie et al. [20], (53.81\%) by Abdulkadir et al. [2] but higher than what was reported by Adewuyi et al. [5] (37.75\%). Variations in properties of oil maybe due to the differences in variety of plant, cultivation, climate, ripening stage, the harvesting time of the seeds and the extraction methods used [21].

The golden colour possessed by $H$. crepitans oil is the colour of most vegetable oils and would not be detrimental to the final colour of the article produced. Its smell which is inoffensive conveys the likelihood of the oil not influencing the odour of the finished leather product. The specific gravity of the oil is in line with the density of most vegetable oils [22]. The oil has an iodine value of 117 , which signifies a high quantity of unsaturated fatty acids [22]. The decreased iodine value observed in the sulphonated product signifies a low level of unsaturation as most of the $\mathrm{C}=\mathrm{C}$ bonds in the unsulphonated oils have been used up in the sulphonation reaction. The sulphonated oil produced from the oil has a high percentage of $\mathrm{SO}_{3}(5.87 \%)$. High percentage of $\mathrm{SO}_{3}$ in a fatliquor is an indication of a deeper penetration prospect of sulphonated $\mathrm{H}$. crepitans oil when used in leather fatliquoring [6]. The very pale brown colour of the $10 \%$ solution did not affect the colour of the finished leather product and suggests that the finished leather product could be dyed to any choice of colour by the tanner. 
Similarly, the sulphonated oil which is odourless, has no influence on the final odour of the produced leather unlike most leather products with a unique fishy smell.
Contrary to previous published works [23$25]$, the fatliquor detailed in this work is virtually free from inorganic salts; a disparity likely caused by differences in the method of production.

Table 2: Physicochemical properties of both unsulphonated and sulphonated $\mathrm{H}$. crepitans oils

\begin{tabular}{|c|c|c|}
\hline Parameter & Unsulphonated oil (HCO) & Sulphonated oil (SHCO) \\
\hline Percentage Yield (w/w\%) & 52.76 & 74.86 \\
\hline Colour & Golden yellow & Brown red \\
\hline Odour & Inoffensive & Odourless \\
\hline Appearance of $10 \%$ Solution & - & Translucent \\
\hline Colour of $10 \%$ solution & - & Very pale brown liquid \\
\hline $\mathrm{pH}$ of $10 \%$ Solution & - & 7.36 \\
\hline Stability of $10 \%$ solution & - & Stability $>24 \mathrm{hrs}$ \\
\hline$\%$ Ash Content & - & Trace \\
\hline$\% \mathrm{SO}_{3}$ & - & 5.87 \\
\hline Specific gravity (at $20^{\circ} \mathrm{C}$ ) & 0.920 & 0.942 \\
\hline Acid Value (mg KOH g-1) & 6.17 & 5.93 \\
\hline Free fatty acid (\% oleic acid) & 3.09 & 2.97 \\
\hline lodine value $(\mathrm{g} / 100)$ & 117 & 27 \\
\hline Saponification value $\left(\mathrm{mg} \mathrm{KOH} \mathrm{g}^{-1}\right)$ & 210 & 196 \\
\hline
\end{tabular}

Sulphonation Process

$$
\mathrm{R} \curvearrowright \mathrm{R}^{\mathrm{I}}+\mathrm{H}_{2} \mathrm{SO}_{4} \stackrel{20^{\circ} \mathrm{C}}{\longrightarrow} \mathrm{R} \overbrace{\mathrm{OSO}_{3} \mathrm{H}}^{\mathrm{R}^{\mathrm{H}}} \frac{\mathrm{CH}_{3} \mathrm{CH}_{2} \mathrm{OH}}{\mathrm{NaOH} / \mathrm{CH}_{3} \mathrm{OH}} \underset{\mathrm{OSO}_{3} \mathrm{Na}}{\mathrm{R}} \overbrace{\text { Sulphonated (Sulphated) oil }}^{\mathrm{R}}
$$

Scheme 1. Sulphonation of $H$. crepitans oil to produce sulphonated (Sulphated) oil

The side reaction can be found below:
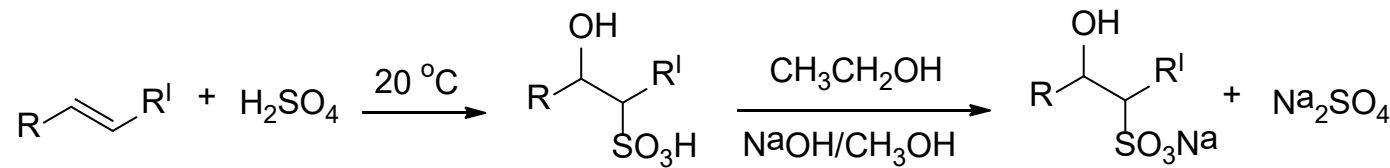

Sulphonated oil (true sulphonates)

Scheme 2. Side by side reaction of the sulphonation of $H$. crepitans oil

Apart from the sulphated and true sulphonates, the reactions (as shown in schemes 1 and 2) also yielded a large quantity of $\mathrm{Na}_{2} \mathrm{SO}_{4}$ (a drying agent), which was vacuum filtered, thus making the sulphonated $H$. crepitans free from water.

\section{Fourier Transform Infra-Red (FT-IR) Results}

The FT-IR spectra of unsulphonated HCO and the corresponding sulphonated SHCO are shown in Figure $1 \mathrm{a}$ and $1 \mathrm{~b}$. In Figure $1 \mathrm{~b}$, the absence of the peak at $3009 \mathrm{~cm}^{-1}$ (C-H stretching frequency of non-conjugated unsaturation) as 
found in Figure 1a depicts the attack of $\mathrm{H}_{2} \mathrm{SO}_{4}$ on the $-\mathrm{C}=\mathrm{C}$ - to form the sulphonated product. In Figure $1 \mathrm{~b}$ the peak at $\sim 1198 \mathrm{~cm}^{-1}$ ( $\mathrm{S}=0$ stretching) is absent in Figure 1a. This confirms the formation of sulphonation reaction. Other prominent peaks found in both samples are at $\left(2853 \mathrm{~cm}^{-1}\right)$ $\mathrm{C}-\mathrm{H}$ stretching frequency of alkene, $\left(1744 \mathrm{~cm}^{-1}\right.$
( $\mathrm{C}=\mathrm{O}$ stretching frequency of ester), $1464 \mathrm{~cm}^{-1}$ (bending frequency of unsaturated alkene), 721 $\mathrm{cm}^{-1}$ (bending frequency of saturated carbon atom). The wide peak in the range at 3200-3600 $\mathrm{cm}^{-1}$ is the $\mathrm{OH}$ stretching of alcohols and could be attributed to traces of alcohol left in the sulphonated product.

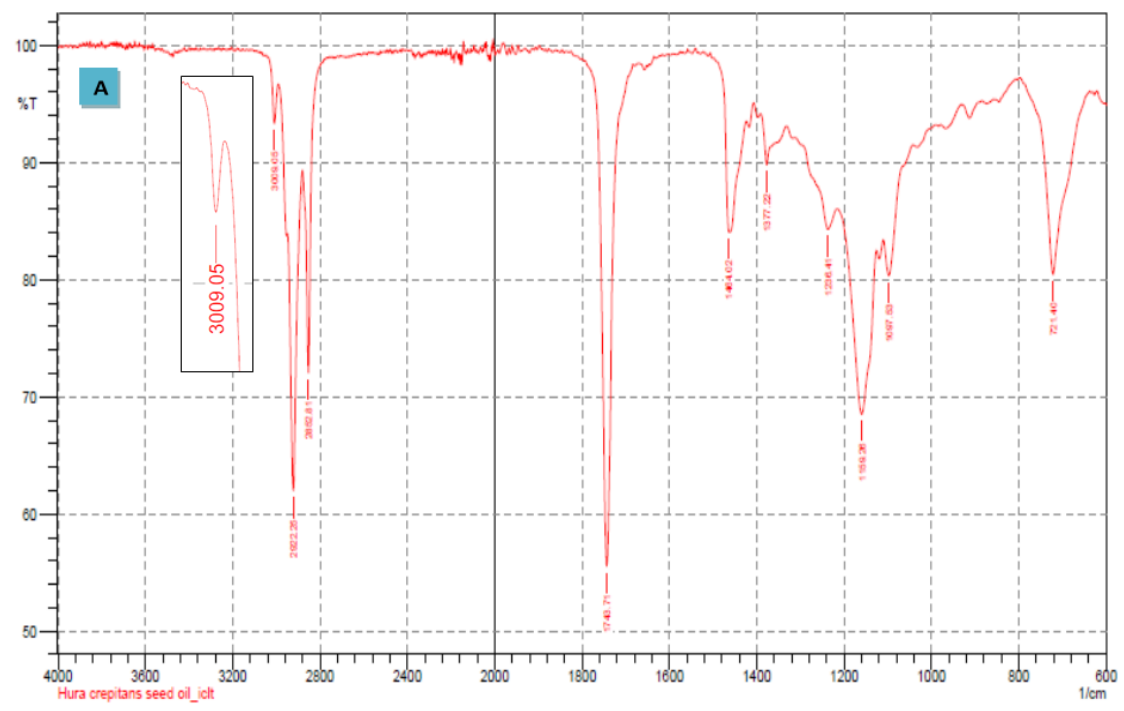

由SHIMARZU

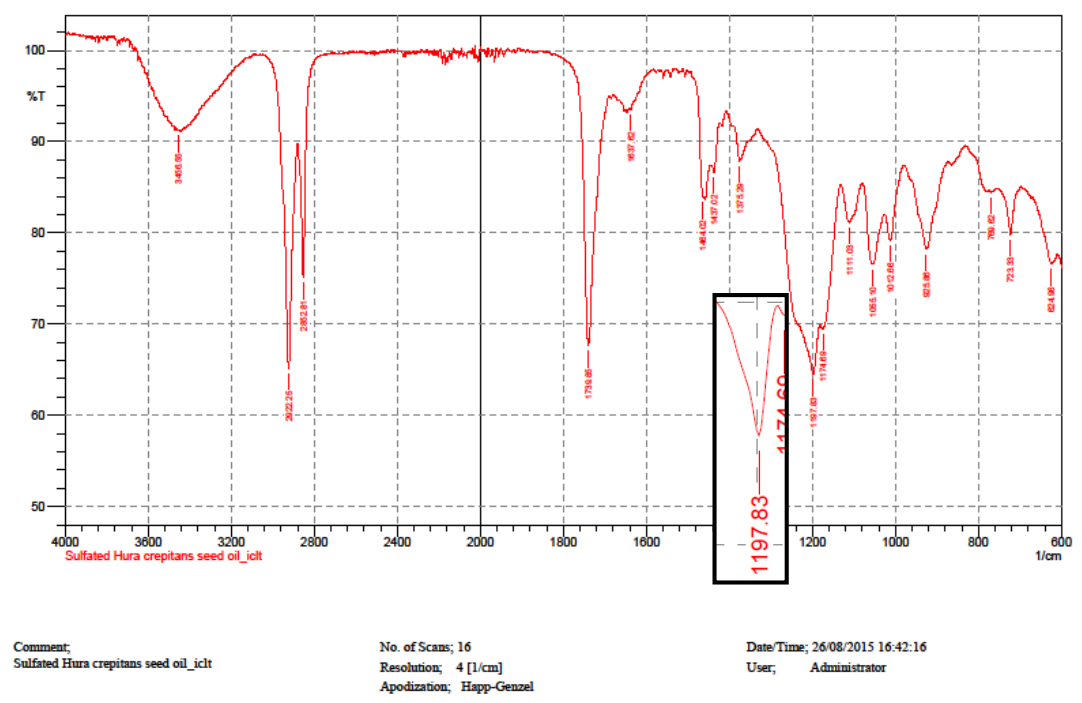

Figure 1. FT-IR spectra of unsulphonated Hura crepitans seed oil (A) (insert: expanded section of signal showing $3009.06 \mathrm{~cm}^{-1}$ ) and sulphonated Hura crepitans seed oil (B) (insert: expanded section of signal showing $1197.83 \mathrm{~cm}^{-1}$ )

Nuclear Magnetic Resonance (NMR) Spectroscopy Results

The ${ }^{1} \mathrm{H}$ NMR of $\mathrm{HCO}$ and $\mathrm{SHCO}$ are shown in Figures $2 \mathrm{a}$ and $2 \mathrm{~b}$ respectively while the ${ }^{13} \mathrm{C}$
NMR and ${ }^{13} \mathrm{C}$ NMR DEPT spectral diagrams are found in Figures $2 c, 2 d, 2 e$ and $2 f$, respectively. 

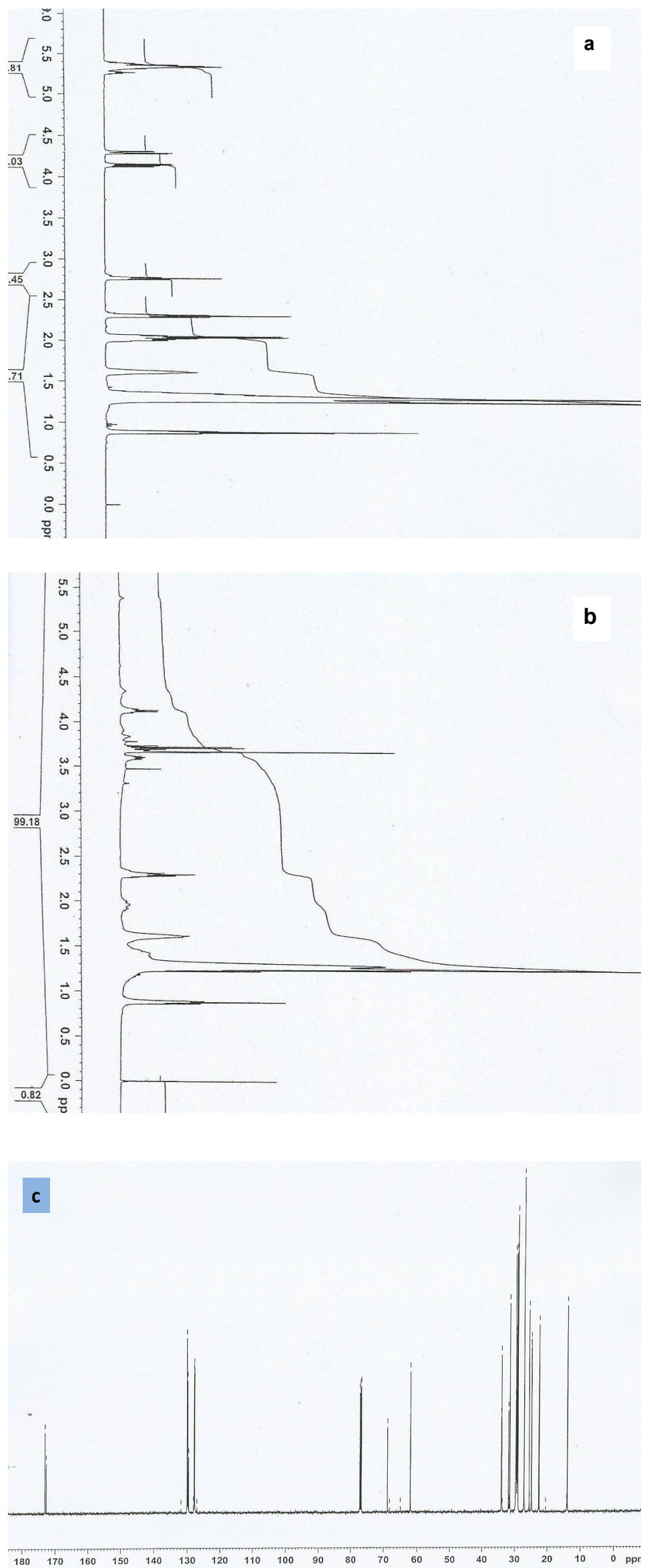

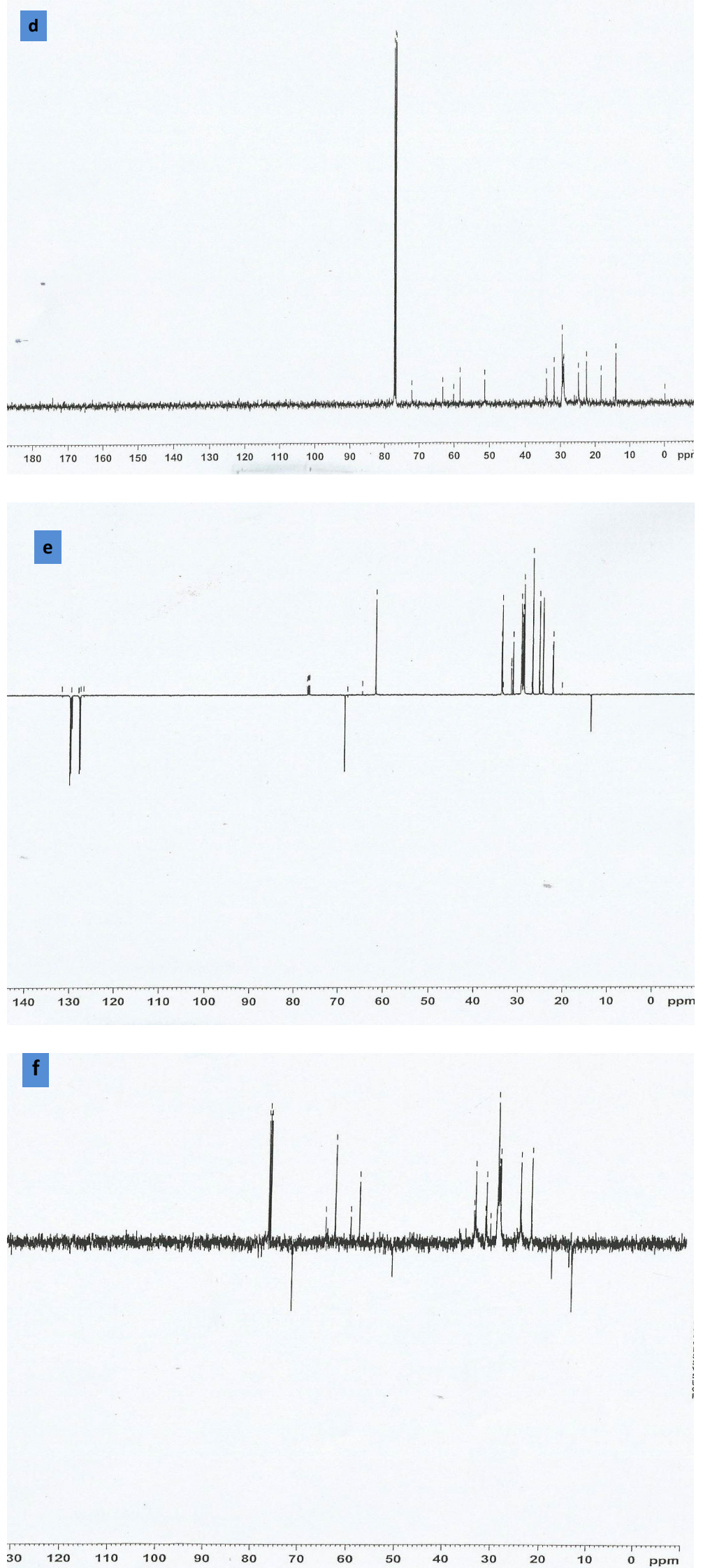

Figure 2. NMR spectroscopy results: (a) ${ }^{1} \mathrm{H}$ NMR of $\mathrm{HCO}$ (b) ${ }^{1} \mathrm{H}$ NMR of SHCO (c) ${ }^{13} \mathrm{C}$ NMR of HCO (d) ${ }^{13} \mathrm{C}$ NMR of SHCO (e) ${ }^{13} \mathrm{C}$ NMR DEPT of HCO (f) ${ }^{13} \mathrm{C}$ NMR DEPT of SHCO in deuterated chloroform 
In the ${ }^{1} \mathrm{H}$ NMR, the multiplet observed at $\delta 5.29$ (Figure 2a), in the unsulphonated oil are due to the olefinic protons attached to the $\mathrm{C}=\mathrm{C}$ double bond. These protons are $\mathrm{sp}^{2}$ hybridized and as such their NMR signals are deshielded by the influence of the diamagnetic anisotropy of the $\pi$ system. Sulphonation / sulphation and sulphitation usually lead to the saturation of the double bond. The $\mathrm{sp}^{3}$ hybridized protons formed are thus expected to be shielded relative to the $\mathrm{sp}^{2}$ olefinic protons. The newly formed protons ( $\mathrm{H}-\mathrm{C}-\mathrm{S}$ or $\mathrm{H}-\mathrm{C}-\mathrm{O})$ in the two reactions formed (scheme 1 and scheme 2 ) showed signals at $\delta 3.6$ and $3.73 \mathrm{ppm}$ (Figure 2b). It is important to note that the slight deshielding observed for these protons relative to the rest of the protons in the sulphonated oil (Figure 2b) is due to the inductive effect of the electronegative sulphur and oxygen atoms. The inductive effect, however, causes less deshielding than diamagnetic anisotropy.

Similar explanation can be used to explain the differences in carbon chemical shifts observed in the ${ }^{13} \mathrm{C}$ NMR for the unsulphonated and sulphonated oils. In the ${ }^{13} \mathrm{C}$ NMR spectra of the unsulphonated oil, (Figure 2c), the methyl group at the end of the acyl chains in glyceride moiety give one signal at around $14.1 \mathrm{ppm}$. It is well separated from other signals and hence easily recognized. The same values have been reported in literature $[22,26,27]$. In the ${ }^{13} \mathrm{C}$ spectrum the signals associated with the olefinic carbons appear highly deshielded at $\delta 127.09$ to $131.85 \mathrm{ppm}$ due to the diamagnetic anisotropic effect of the $\pi$ system. Upon sulphonation, (Figure $2 \mathrm{~d}$ ), these signals disappeared completely due to loss of the double bonds. The new signals which appeared at 52 and $72 \mathrm{ppm}$ belong to the $\mathrm{sp}^{3}$ hybridized carbons ( $\mathrm{C}-\mathrm{S}$ and $\mathrm{C}-\mathrm{O}$ ) formed after the sulphonation reactions. The slightly deshielded position of these signals is also due to the influence of the inductive effect of the electronegative sulphur and oxygen atoms.

From the ${ }^{13} \mathrm{C}$ NMR DEPT spectra diagrams (Figure 2 (e) and (f), the two samples (unsulphonated and sulphonated oils) studied had similar results except for some slight differences observed as a result of the reactions underwent by the sulphonated oils. The terminal $\mathrm{CH}_{3}$ could be seen phased down in both results at $\delta 14 \mathrm{ppm}$. The $\mathrm{C}-\mathrm{H}-\mathrm{O}$ of the glycerol backbone could be seen phased down at $\delta 68$ ppm. In like manner the two $\mathrm{CH}_{2} \mathrm{O}$ of the glycerol backbone phased up and were seen at $\delta 64 \mathrm{ppm}$ and 62 ppm. The $-\left(\mathrm{CH}_{2}\right)_{2}$ of the fatty acid chains phased up an were seen at various positions $\delta$ 20-30 $\mathrm{ppm}$. The evidence of the formation of C-O-S and $\mathrm{C}$-S bonds by the reaction with $\mathrm{H}_{2} \mathrm{SO}_{4}$ was shown by the absence of the $\mathrm{HC}=\mathrm{CH}$ previously found phased down in unsulphonated oils $\delta 127 \mathrm{ppm}$ and $131.87 \mathrm{ppm}$ in the sulphonated oils. The C-O-S was observed phased up $\delta 65.27 \mathrm{ppm}$ in the sulphonated oils and C-S bonds were equally observed phased up at various positions $\delta 60.16$ ppm and $58.38 \mathrm{ppm}$. These C-O-S and C-S bonds were completely absent in the unsulphonated oils. Also, the additional signals at $51.44 \mathrm{ppm}$, $58.38 \mathrm{ppm}$ which represent the -C-S peaks and the signal at $72.17 \mathrm{ppm}$ which represent the -C-O-S peak are completely absent in the starting $\mathrm{HCO}$.

\section{Characterisation of the Sulphonated Oil}

The stability test results (Table 3 ) show that $10 \%$ fatliquor emulsions of sulphonated $H$. crepitans oil is generally stable in various salt solutions used in leather manufacturing processes like deliming and pickling solutions. As soon as a stable emulsion particle hits the fibre structure, the sulpho fraction interacts electrostatically with it, causing the emulsion to lose its emulsifier and the neutral oil will be deposited (Fixation) [6].

The sulphonated oil had good emulsion stability towards pickle liquor and hard water but unstable when in contact with formic acid. Anionic fixation takes place only in acid medium. This is because collagen at a $\mathrm{pH}<$ IEP becomes cationic and therefore anionic fatliquors are 
fixed. Addition of $10 \%$ emulsion of sulphonated oil ( $\mathrm{pH}$ of 7.36) brings about an increase in the $\mathrm{pH}$ of $5 \%$ Chromium sulphate ( $\mathrm{pH}$ of about 3 ) to a higher $\mathrm{pH}$ of about 3.8 to 4.2. This leads to the destabilisation of the emulsion and phase separation occurs thereby making it stable after about an hour. The table also shows that the prepared fatliquor can be used in the retanning and fatliquoring steps.

Differential Scanning Calorimetry (DSC)
Table 3: Stability of $10 \%$ fatliquor emulsion towards pickle liquor, tan liquor and hard water

\begin{tabular}{cc}
\hline Solution added & Stability Status \\
\hline $5 \%$ Basic chromium sulphate & Stable (1 hour) \\
(tan liquor) & Stable \\
$5 \% \mathrm{MgSO}_{4}$ (hard water) & Stable \\
$5 \% \mathrm{NaCl}$ (found in pickle liquor) & Unstable \\
$5 \%$ Formic acid &
\end{tabular}

Table 4: The thermal behaviour of $\mathrm{HCO}$ and SHCO

\begin{tabular}{cccc}
\hline Oil Sample & Onset Temperature $\left({ }^{\circ} \mathrm{C}\right)$ & Peak Temperature $\left({ }^{\circ} \mathrm{C}\right)$ & $\begin{array}{c}\text { Endset Temperature } \\
\text { (Melting Point) }\left({ }^{\circ} \mathrm{C}\right)\end{array}$ \\
\hline Unsulphonated & $-30.85+0.40$ & $-23.88+0.08$ & $-15.21+0.53$ \\
Sulphonated & $-10.17+1.05$ & $3.48+0.25$ & $11.91+0.12$ \\
\hline
\end{tabular}

A higher melting point found in the sulphonated oil signifies a phase transition and could be an indication that most of the unsaturated fatty acids have been used up in the sulphonation reaction; leaving behind saturated fatty acids (which have a higher melting point) than unsaturated fatty acid [28]. The DSC results also show that the oils are very stable within the temperature range studied.

\section{Mechanical Properties of the Leather Samples}

Mechanical properties of the leather samples were shown in Table 5.

Table 5: Mechanical properties of the leather samples

\begin{tabular}{ccccc}
\hline Properties & NC & PC & Pure & Blend \\
\hline Average Softness & 25.8 & 32.6 & 32.2 & 33.4 \\
Average tear load (N) & 352.5 & 409.2 & 505.5 & 613.3 \\
Average Tensile strength (N/mm $)$ & 15.66 & 20.62 & 23.51 & 26.13 \\
Average elongation at break (\%) & 34.79 & 41.86 & 36.40 & 45.02 \\
Average grain crack strength (N) & 200 & 330 & 410 & 370 \\
Average Ball burst strength (N) & 380 & 435 & 500 & 480 \\
\hline
\end{tabular}

Note: $\mathrm{NC}=$ Negative control (without fatliquor), $\mathrm{PC}=$ Positive control (with commercial fatliquor), $\mathrm{Pure}=$ with pure sulphonated $\mathrm{H}$. crepitans oil, Blend $=$ a blend of pure sulphonated $\mathrm{H}$. crepitans oil and $7.5 \%$ raw castor oil

It is evident from the strength or mechanical properties results that the leather fatliquored using sulphonated $H$. crepitans seed oil has better properties than the commercial fatliquor. The value of the mean tensile strength of the negative control (leather processed without fatliquor) was very low $\left(15.66 \mathrm{~N} / \mathrm{mm}^{2}\right)$ when compared with that of the fatliquored leather samples - PC $\left(20.62 \mathrm{~N} / \mathrm{mm}^{2}\right)$, A1 $(23.51$
$\mathrm{N} / \mathrm{mm}^{2}$ ). This can even be improved by the addition of $7.5 \%$ castor seed oil A2 (26.13 N/ $\mathrm{mm}^{2}$ ). (Castor oil is normally used in the tanning industry as a source of lubrication because of its humectant property). These enhancements in the strength properties of the leather from prepared fatliquors result from good lubrication of the leather fibres [29]. 

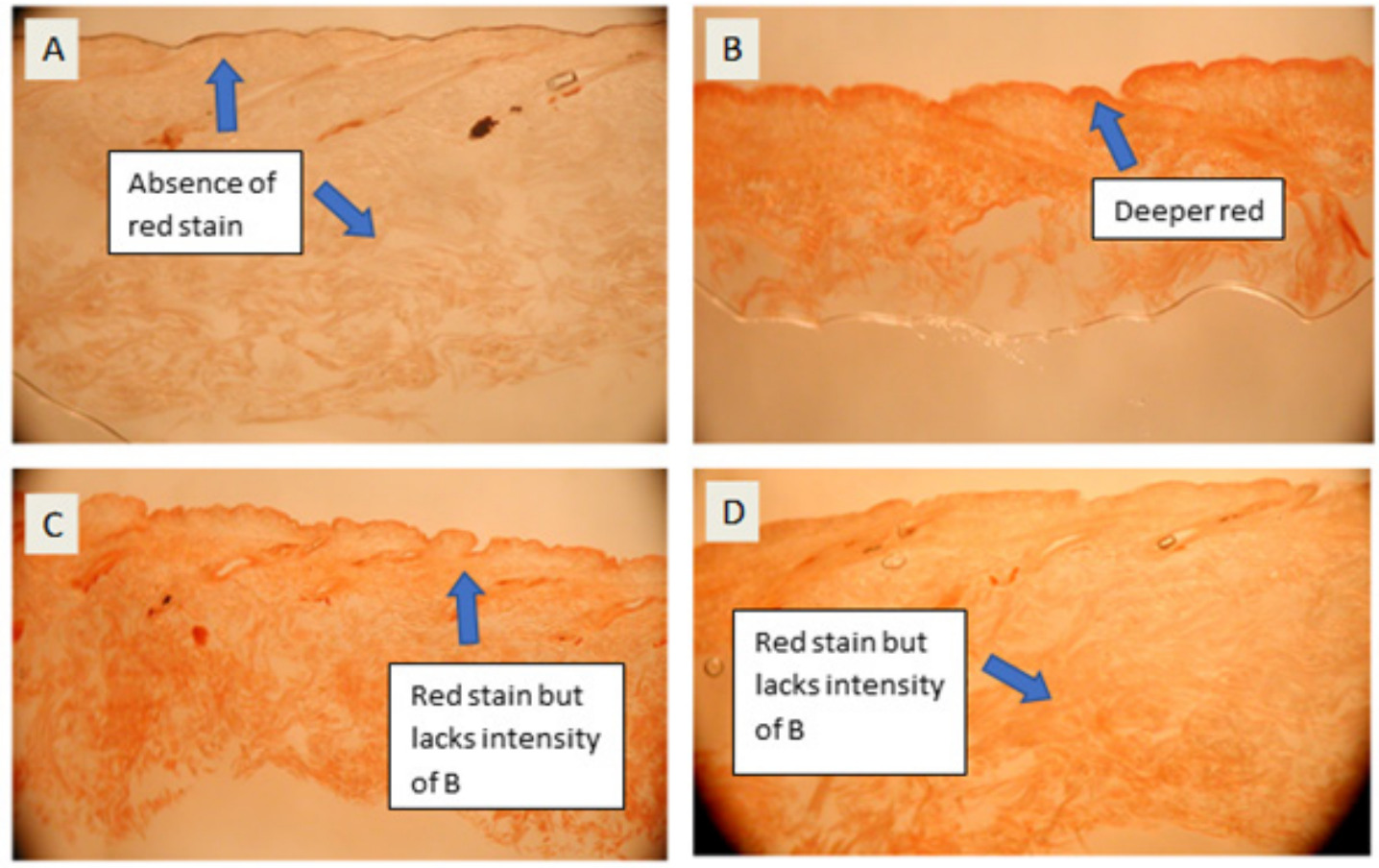

Figure 3. Staining test results showing cross section of goatskins fatliquored with: A) without fatliquor; B) with pure sulphonated $H$. crepitans fatliquor; C) with a blend of pure sulphonated $H$. crepitans fatliquor and $7.5 \%$ raw castor oil; D) with commercial fatliquor

The development of a deepening red colour in the stain as the figures move from Figure $3 a$ to $3 b$ signifies that the Sudan stain confirms the penetration of the sulphonated oils into the leather fibre structure [30].

Figure $3 b, 3 c$, and $3 d$ all show a deep penetration of fatliquor. The intensity of the red colour seen in Figure $3 b-d$ indicates that the Sudan stain is detecting the presence of fats. Figure $3 a$ indicates that no fat is present in the material. Figure $3 \mathrm{c}$ and $3 \mathrm{~d}$ indicate that fatliquor is present, but the grain layer is not as deep in red colour as can be seen in Figure 3b. Surface lubrication is vital for grain strength when a leather is placed on the shoe last.

\section{CONCLUSIONS}

The sulphonation of $H$. crepitans seed oil (oil from underutilized seeds of no known market value), has been confirmed by the structural characterizations performed by FT-IR, ${ }^{1} \mathrm{H} N M R$ and ${ }^{13} \mathrm{C}$ NMR analysis. The sulphonated oil has no odour which will affect the smell of the finished leather product and is quite stable in pickle liquor and hard water.
The leather processed by the sulphonated $H$. crepitans fatliquor had better tensile strength, double edge tear, and grain strength than that processed with commercial/imported fatliquor. This provides evidence that the sulphonated $H$. crepitans fatliquor is comparable and could even outperform commercial products for the production of leather shoe upper. It highlights the suitability of sulphonated fatliquor made from $H$. crepitans - a quite sustainable source.

\section{Acknowledgements}

The authors thank the management and staff of the Institute for Creative Leather Technologies (ICLT), University of Northampton, (UoN) Northampton, United Kingdom for the support in terms of facilities, equipment and bench space offer for the work.

\section{Funding Sources}

This research did not receive any specific grant from funding agencies in the public, commercial, or not-for-profit sectors. 


\section{REFERENCES}

1. Keay, R.W.J., Onochie, C.F.A., Stanfield, D.P., Trees of Nigeria, Revised Version Vols. 1 and 2, 1989, National Press Ltd., Apapa Lagos, Published by the Department of Forestry Research Institute, Ibadan, p. 174-175.

2. Abdulkadir, M.N., Amoo, I.A., Adesina, A.O., Chemical Composition of Hura crepitans Seeds and Antimicrobial Activities of its Oil, Int J Sci Res (Ahmedabad), 2013, 12, 440-445.

3. Oyeleke, G.O., Olayiwola, O.A., Latona, D.F., Chemical Examination of Sandbox (Hura crepitans) Seed: Proximate, Elemental and Fatty Acid Profile, IOSR J of Appl Chem (IOSRJAC), 2012, 1, 1013, www.iosrjournals.org, https://doi. org/10.9790/5736-0121013.

4. Umoren, S.A., Umoren, I.U., Johnson, A.S., Metal soaps of Hura crepitans seed oil: Potential Stabilizer for Unplasticised Polyvinyl Chloride against Thermal Degradation, Journal of Chemical Acta, 2013, 2, 92-94.

5. Adewuyi, A., Awolade, P.O., Oderinde, R.A., Hura crepitans Seed Oil: An Alternative Feedstock for Biodiesel Production, Journal of Fuels, 2014, 1-9, https://doi. org/10.1155/2014/464590.

6. Covington, A.D., Tanning Chemistry: The Science of Leather, 2011, Royal Society of Chemistry.

7. Zarlok, J., Smiechowski, K., Mucha, K., Tecza, A., Research on Application of Flax and Soya Oil for Leather Fatliquoring, $J$ Clean Prod, 2014, 65, 583-589, https:// doi.org/10.1016/j.jclepro.2013.07.044.
8. Krishnan, S.H., Sundar, V.J., Rangasamy, T., Muralidharan, C., Sadulla, S., Studies on Chamois Leather - Tanning Using Plant Oil, J Soc Leath Tech Ch, 2005, 89, 260-262.

9. Dashe, B.B., Ukoha, P.O., Ejila, A., Fatliquoring Potential of Groundnut (Arachis hypogae), Palm Kernel Oils, Proceedings of the XXV IULTCS Congress, 1999, India, p. 237-241.

10. Roy, S., Riga, A.T., Alexander, K.S., Experimental Design Aids and the Development of Differential Scanning Calorimetry Standard Test Procedure for Pharmaceuticals, Thermochim Acta, 2002, 392-393, 399-404, https://doi. org/10.1016/S0040-6031(02)00317-9.

11. Nassu, R.T., Gonçalves, L.A.G., Determination of Melting Point of Vegetable Oils and Fats by Differential Scanning Calorimetry (DSC) Technique, Grasas y Aceites, 1999, 50, 16-22, https:// doi.org/10.3989/gya.1999.v50.i1.630.

12. Society for Leather Technologists and Chemists, SLTC methods, 1996, SLTC, Withernsea, UK.

13. British Standards Institution, Chemical, Physical and Mechanical and Fastness tests. Sampling location, BS EN ISO 2418:2002.

14. Institute for Creative Leather Technologies, Leather Manufacture: Shoe Upper-Chromium (Non-Compact) ICLT SR 15/31, 2015.

15. British Standards Institution, Chemical, Physical and Mechanical and Fastness tests. Conditioning. BS EN ISO 2419:2002. 
16. British Standards Institution, Leather. Physical and Mechanical tests. Determination of Softness, BS EN ISO 17235:2015.

17. British Standards Institution, Leather. Physical and Mechanical tests. Determination of Tensile Strength and Percentage Extension. BS EN ISO 3376:2011.

18. British Standards Institution, Leather. Physical and Mechanical tests. Determination of Tear Load. Double edge tear. BS EN ISO 3377-2:2011.

19. British Standards Institution, Leather. Physical and Mechanical Tests. Determination of Distension and Strength of Surface (Ball Burst method) BS EN ISO 3379:2015.

20. Okolie, P.N, Uaboi-Egbenni, P.O., Ajekwene, A.E., Extraction and Quality Evaluation of Sandbox Tree Seed (Hura crepitans) Oil, World Journal of Agricultural Sciences, 2012, 8(4), 359-365.

21. Nzikou, J.M., Mvoula-tsiéri, M., Ndangui, C.B., Pambou-Tobi, N.P.G, Kimbonguila, A., Loumouamou, B., Silou, T.H., Desobry, S., Characterization of Seeds and Oil of Sesame (Sesamum indicum L.) and the Kinetics of Degradation of the Oil During Heating, Research Journal of Applied Sciences, Engineering and Technology, 2010, 2, 227-232.

22. Gunstone, F.D., The Chemistry of Oils and Fats: Sources, Composition, Properties and Uses, Blackwell Pub Ltd, Oxford, UK, 2004, p. 100-139.
23. Quadery, A.H., Uddin, T., Azad, A., Chowdhury, M.J., Deb, A.K., Hassan, N., Fatliquor Preparation from Karanja Seed Oil (Pongamia pinnata L.) and its Application for Leather Processing, IOSR Journal of Applied Chemistry, 2015, 8, 54-58.

24. Olawale A.S., Eleonu, C.E., Castor Oil/ Rubberseed Oil Blend as a leather lubricant, J Soc Leath Tech Ch, 2001, 86, 55-58.

25. Affiang, S.D., Ggamde, G., Okolo, V.N., Olabode, V., Jekkada, J.Z., Synthesis of sulphated-fatliquor from neem (Azadirachta indica) seed oil for leather tannage, American Journal of Engineering Research, 2018, 7, 4, 215-221.

26. Okieimen, F.E., Pavithran, C., Bakare, I.O., Epoxidation and hydroxlation of rubber seed oil: One-pot multi-step reactions, Eur J Lipid Sci Technol, 2005, 107, 330-336, https://doi.org/10.1002/ejlt.200401126.

27. Sega, A., Zanardi, I., Chiasserini, L., Gabbrielli, A., Bocci, V., Travagli, V., Properties of sesame oil by detailed $1 \mathrm{H}$ and $13 C$ NMR assignments before and after ozonation and their correlation with iodine value, peroxide value and viscosity measurements, Chem Phys Lipids, 2010, 163, 148-156, https://doi.org/10.1016/j. chemphyslip.2009.10.010.

28. Berg, M.J., Tymoczkko, J.L., Styrer, L., Biochemistry, ISBN-10: 0-7167-3051-0, $5^{\text {th }}$ edition, New York, 2002.

29. Burgess, D., General Aspects of Fatliquoring: An Introduction to the Application and Chemistry of Fatliquoring, J Soc Leath Tech Ch, 1993, 78, 39-43. 
30. Waite, T., Oils, Fats, Waxes and Fatliquors, in: Leather Technologists Pocket book, Ed: Leafe, M. K. Society of Leather Technologists and Chemists, 1999, Withernsea, UK., p. 125-148.
(C) 2019 by the author(s). Published by INCDTPICPI, Bucharest, RO. This is an open access article distributed under the terms and conditions of the Creative Commons Attribution license (http:// creativecommons.org/licenses/by/4.0/). 